\title{
PRODUCTION AND DISTRIBUTION OF VALUE
}

\section{PRODUCCIÓN Y DISTRIBUCIÓN DE VALOR}

\author{
Daniel Villalobos Céspedes ${ }^{1}$
}

Recibido: 29/06/2019

Aprobado: 24/01/2022

\begin{abstract}
The fundamental contribution of this research is regarding five of Cobb and Douglas's core questions that we believe the theory of economic growth has not made clear until now. The answers we provide are an attempt to measure relative and total resource contribution to production growth and its distribution between them. It implies paying close attention to the latest refinement of the theory and dealing with new critical assumptions, key formulas, and method of attack. The evaluation of these efforts by Cobb and Douglas's data support the hypothesis that distribution processes are modeled by those of the production of value. The scope of this research could motivate further progress in the study of economic growth.
\end{abstract}

KEYWORDS: COBB AND DOUGLAS; ELASTICITY OF RESOURCE COMPOSITION; ELASTICITY OF DISTRIBUTION.

JEL CLASSIFICATION: 040

\section{RESUMEN}

La contribución fundamental de esta investigación es atender cinco de las preguntas centrales de Cobb y Douglas que pensamos no resueltas todavía por la teoría del crecimiento económico. Las respuestas que brindamos son un intento de medir la contribución relativa y total de los recursos al crecimiento de la producción y su distribución. Implica prestar mucha atención al último refinamiento de la teoría y establecer nuevos supuestos críticos, fórmulas clave y métodos de ataque. La evaluación de estos esfuerzos con los datos de Cobb y Douglas soporta la hipótesis de que los procesos de distribución se modelan por los de producción. El alcance de esta investigación podría motivar mayores avances en el estudio del crecimiento económico.

PALABRAS CLAVE: COBB Y DOUGLAS; ELASTICIDAD-DE-COMPOSICIÓN DE LOS RECURSOS; ELASTICIDAD-DE-DISTRIBUCIÓN.

CLASIFICACIÓN JEL: 040

1 Universidad Nacional de Costa Rica, Escuela de Administración; Código Postal: 86-3000; Heredia, Costa Rica; daniel.villalobos.cespedes@una.cr

Universidad de Costa Rica, Sede del Pacífico, Escuela de Administración de Negocios; Puntarenas, Costa Rica 


\section{INTRODUCTION}

The Theory of Production Growth by Cobb and Douglas (1928) is an attempt to explain the relation between capital, labor, and production of values. These authors criticized "the progressive refinement...in the measurement of the volume of physical production in" United States manufacturing, concluding that such relation "is purely fortuitous" and arguing that it is a "reductio ad absurdum" (Cobb \& Douglas, 1928, pp. 139, 160). The start of their endeavor to "deal with" and "to throw some light upon" it is based on the following questions:

- Can we estimate, within limits, whether this increase in production was purely fortuitous, whether it was primarily caused by technique, and the degree, if any, to which it responded to changes in the quantity of labor or capital?

- May it be possible to determine, [...], the relative influence upon production of labor as compared with capital?

- As the proportion of labor to capital changed from year to year, may it be possible to deduce the relative amount added to the total physical product by each unit of labor and capital and what is more important still by the final units of labor and capital in the respective years?

- Can we measure the probable slopes of the curves of incremental product which are imputed to labor and capital and thus give greater definiteness to what is at present purely a hypothesis with no quantitative values attached?

- ...may we shed light upon the question as to whether or not the processes of distribution are modeled at all closely upon those of the production of value? (Cobb \& Douglas, 1928, pp. 139-140)

So, it is the purpose of this research to offer a method of analysis to discover new results and to provide some answers to those questions, focusing on developing a "method of attack" according to the following Cobb and Douglas' suggestion and challenge:

We should (1) be prepared to devise formulas which will not necessarily be based upon constant relative 'contributions' of each factor to the total product but which will allow for variations from year to year, and (2) will eliminate so far as possible the time element from the process. (Cobb \& Douglas, 1928, p. 165)

The previous suggestion and challenge are the core points in this research's attempt to find answers to those questions. But before doing it, in the first section, we will work with some remarkable authors like Swan (1956), Solow (1956) and (1957), Arrow et al. (1961), and recently Piketty (2014a), all of which perform amazing efforts in giving answers to those questions. But no endeavor of these authors satisfies Cobb and Douglas's suggestion, challenge, and questions. By working with Cobb and Douglas's production function, part two of this research will offer new formulas which measure $(\alpha)$, "the elasticity of the product with respect to small changes in labor alone" (Cobb \& Douglas, 1928, pp. 155-156), and thus the slope of production function. Cobb and Douglas's data is useful in revealing results shown in tables and figures. The third section deals with further assumptions to analyze the process of distribution of value. From there, the elasticity of distribution $(\beta)$ shows as an original result by developing another new formula that measures the elasticity of resource composition $(\mu)$. To evaluate these findings, we will use Cobb and Douglas's data. 
We conclude that "the processes of distribution are modeled at all closely upon those of the production of value" (Cobb \& Douglas, 1928, pp. 139-140, 161). Neither production growth nor distribution of production are purely fortuitous; they might be caused by technique and the degree to which it responds to changes in the quantity of labor or capital (Cobb \& Douglas, 1928, pp. 139140 ) and business cycle, wars, and government policies. Those processes reveal the convergence and divergence phenomenon in economic growth. Finally, conclusions and possible refinements to the theory of economic growth will be stated followed by the bibliography.

\section{Progressive Refinement in Economic Growth Theory}

Cobb and Douglas's theory on production growth suggests that it is valid as a result of the United States manufacturing analysis during 1899-1922 (Cobb \& Douglas, 1928, pp. 159-164). Nevertheless, in "A Program for Further Work" these authors advice: "It should be made clear that we do not claim to have actually solved the law of production, but merely that we have made an approximation to it and suggested a method of attack" (Cobb \& Douglas, 1928, pp. 164-165). Since Cobb and Douglas, "progressive refinement" on the theory represents remarkable efforts in finding new answers to those questions. Even though Harrod (1939) did not have the intention of answering those questions, he proposed:

a new method of approach [to] the study of the operations of the forces maintaining a trend of increase [because] even in a condition of growth, which generally speaking is steady, it is not to be supposed that all the component individuals are expanding at the same rate. (pp. 15-16)

He insisted on it in his "second essay in dynamic theory" (Harrod, 1960, p. 281). Cobb and Douglas's questions imply that resources' relative contributions to production growth must converge with comparative distributions of value. Harrod (1960) assumes "constant income distribution," but:

This assumption is simply carried over from the welfare optimum of static economics, where the income distribution is taken as given. Ultimately, we should be able to accommodate a steadily changing distribution of income in dynamic theory; this would (or might) entail a steadily changing rate of growth. (p. 282)

\section{Swan's Basic Formula}

Swan (1956) aggregated the rate of saving to measure the annual addition to the capital stock as a ratio of saving to output: $d K=s Y$. Assuming that capital and labor are paid relative contribution to production growth, Swan (1956) affirmed, "The relative shares of total profits and total wages in income are constants, given by the production elasticities $\alpha$ and $\beta$ " (p. 335) where $(\alpha, \beta)$ measures, correspondingly, the relative contributions of capital $(K)$ and labor $(L)$ to production $(Y)$ growth; furthermore, the ratios $(Y / K, Y / L)$ measure the average product of capital and labor with which he arrives at the relative shares. Swan (1956) distinguishes between resources' relative contribution to production growth and the relative distribution of value (Villalobos, 2020). He makes it clear that the share of resources on production growth depends on its contribution; "the forces of perfect competition drive the 
rate of profit or interest $[r]$ and the (real) wage rate $[\mathrm{W}]$ into equality with the marginal productivities of capital and labor, derived from the production function" (Swan, 1956, p. 335).

Swan's basic formula of production growth surges from the definition of marginal products; for labor $\left[\partial Y / \partial L=\beta Y / L:: y_{L}=\beta n\right]$ and for capital $\left[\partial Y / \partial K=\alpha Y / K: y_{K}=\alpha k\right]$ where $(k, n)$ represent the relative rates of capital and labor increment, so that the relative rates of capital and labor contribution to production growth define the relative rate of production growth (Swan, 1956):

$$
y=\left(y_{K}, y_{L}\right)=(\alpha k, \beta n)
$$

which in terms of income is equals to:

$$
y=(s r, n w)
$$

\section{Solow's Fundamental Equation}

Solow assumes that 1 . There is only one commodity, output as a whole, whose rate of production is designate $Y(t)$; where $(t)$ represents time, in each instant of production. 2. Part of each instant's output is consumed and the rest is saved and invested. 3. The fraction of output saved is a constant s, so that the rate of saving is $s Y(t)$. 4. The community's stock of capital $K(t)$ takes the form of an accumulation of the composite commodity. Net investment is then just the rate of increase of this capital stock $\bar{K}=d K / d t$, so we have the basic identity at every instant of time: $K=s Y$, as found in Swan (1956). 5. Output is produced with capital and labor, whose rate of input is $L(t)=L_{0} e^{n t}$. Solow's production function is $Y=F(K, L)$ where "constant returns to scale seems the natural assumption to make in a theory of growth" Solow (1956, pp. 66-67). Hence, $d K=s Y$, so that:

$$
k=S Y / K
$$

Inserting $Y=F(K, L)$ into the previous equation will result in:

$$
k=S F(1, L / K)
$$

By the derivative of the ratio capital/labor $(r=K / L)$ such that $(\dot{r}=k-n)$ it states that the relative rate of growth of resource composition $(i)$ is the difference of the relative rate of growth in capital $(k)$ and in labor (n). Inserting equation (4) into this definition results:

$$
\dot{\mathrm{r}}=S F(1,1 / r)-n
$$

This is Solow's fundamental equation in terms of relative rate of change on resource composition; it is found by multiplying both sides of equation (5) by (r) and "it is the total product curve as varying amounts $r$ of capital are employed with one unit of labor. Alternatively, it gives output per worker as a function of capital per worker [....] [It] states that the rate of change of the capital-labor ratio is the difference of two terms, one representing the increment of capital and one the increment of labor" (1956, p. 69).

Equation (5) can be simplified in terms of the average capital contribution to production growth $\left(\bar{y}_{K}\right)$ :

$$
\dot{r}=s \bar{y}_{K}-n
$$

If the relative contribution of capital to production growth is $[\partial Y / \partial K=\alpha Y / K]$, from equation

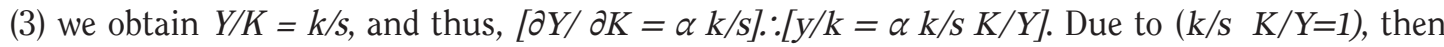


$\mathrm{y}_{\mathrm{K}}=\alpha \mathrm{k}$. From equation (6), $(\dot{r}=k-n)$ and let $\bar{y}_{K}=F(1,1 / r)$, and then, $\mathrm{k}-\mathrm{n}=\mathrm{s} \overline{\mathrm{K}}_{\mathrm{K}}-\mathrm{n} \cdot \mathrm{k}=\mathrm{s} \overline{\mathrm{y}}_{\mathrm{K}}$ and $\mathrm{y}_{\mathrm{K}}=\alpha s \bar{y}_{K}$. Labor relative contribution to production growth is $\left[\partial Y / \partial L=\beta Y / L: y_{L}=ß n\right]$. Solow's fundamental formula can be expressed as Swan's basic formula, and thus, capital and labor income are also the same as stated by both authors: $r=\alpha Y / K$. From equation (3), $k / s=Y / K$ so $r s=\alpha k$ such that $\alpha k=\alpha s \bar{y}_{K}$ :

$$
k=s \bar{y}_{K}
$$

which is both authors' assumption of relative increments on capital. Labor income is $W=\beta Y / L$ and $y / n=\beta$ so that $w=y / n \quad Y / L \therefore n w=y_{L} Y / L$. Hence, the equivalent Swan-Solow's function of relative production growth could be:

$$
y=\left(\alpha s \bar{y}_{K}, n w\right)=(s r, n w)
$$

And the "possible growth patterns" (Solow, 1956, p. 68) cannot provide the specific answers required by Cobb and Douglas's questions. If the relative income in the economy ( $\varpi)$ is the sum of capital and labor relative income, then $s r=\alpha k$. By equation (7) $s r=\alpha s \bar{y}_{K} \therefore r=\alpha \bar{y}_{K}$, while for labor $W=\beta \bar{y}_{L}$ where $\bar{y}_{L}$ represent the average labor contribution to production growth; hence:

$$
\pi=(r, W)=\left(\alpha \bar{y}_{K}, \beta \bar{y}_{L}\right)
$$

\section{A New Class of Production Functions}

Arrow et al. (1961) researched capital and labor substitution to analyze the relative share of those resources on production growth. Their production function assumes homogeneity, constant elasticity of substitution between capital and labor, which might be different among industries in an economy, and thus it is characterized by substitution, distribution, and efficiency parameters. Basically, these authors magnified and attempted to empirically apply Solow's fundamental equation examined in previous paragraph, and his "novelty to suggest":

To describe [...] an elementary way of segregating variations in output per head due to technical change from those due to changes in the availability of capital per head [...] technical change [...] as a short hand expression for any kind of shift in the production function. (Solow, 1957, p. 312)

Their formula involves value added $(Y)$, capital $(K)$, and labor input in man-years $(L)$, so that:

$$
Y=F(K, L)
$$

If $(r=K / L)$ so $(K=r L)$, which when replaced into function (10) will yield $Y=F(r L, L)$ whence $Y / L=F(r, 1)$, and if $\bar{y}_{L}=Y / L$, the average value added for labor, then:

$$
\bar{y}_{L}=F(r, 1)
$$

It is also true that $[r=K / L \therefore L=1 / r K]$, which when inserted into equation (10) provides $Y=F(K, 1 / r K) \therefore Y / K=F(1,1 / r)$ and being that $\bar{y}_{K}=Y / K$ the result will be:

$$
\overline{\mathrm{y}}_{\mathrm{K}}=\mathrm{F}(1,1 / \mathrm{r})
$$


This means that the average contribution of capital might change at an additional unit of capital for each added unit of labor at constant returns.

By the definition of marginal product of labor and capital $[\partial Y / \partial L=(1-\alpha) Y / L ; \partial Y / \partial K=\alpha Y / K]$ and replacing functions (11) and (12), respectively, $[\partial Y / \partial L=(1-\alpha) F(r, 1)] ;[\partial Y / \partial K=\alpha F(1,1 / r)]$ and let $[W=\partial Y / \partial L ; r=\partial Y / \partial K]$, so that:

and

$$
W=(1-\alpha) F(r, 1)
$$

$$
r=\alpha F(1,1 / r)
$$

The ratio between these two functions will give:

$$
W / r=[(1-\alpha) / \alpha] r
$$

which is the elasticity of the rate of return with respect to the wage rate (Arrow, Chenery, Minhas, \& Solow, 1961). If ( $\alpha$ ) is given, its relative share on production growth will oscillate with changes on (r).

\section{Piketty: Beyond Cobb-Douglas}

Piketty (2014a) supposes having questioned Cobb and Douglas's (1928) stability of the relative contribution of resources to production $(\alpha)$ :

With a Cobb-Douglas production function, no matter what happens, and in particular no matter what quantity of capital are available, the capital share of income is always equal to the fix coefficient $\alpha$, which can be taken as a purely technological parameter. (p. 218)

Nevertheless, this author 1) equates his coefficient $\alpha$ named "share of income" with Cobb and Douglas's $\alpha$ "elasticity of the product with respect to small changes in labor alone" (Cobb \& Douglas, 1928, p. 156) or relative contribution of labor to production growth, and 2) perhaps he did not pay attention to Cobb and Douglas's (1928) next explanation:

It should be born in mind, however, that our results have been given exact numerical value for the sake of fixing the idea. But the numbers themselves are fixed tentatively relative to a certain period and to certain indices. When the indices are refined or the period is changed it may be that the constant $3 / 4$ will appear as a constant .7 or .6 or perhaps as a variable. Even the form of the function $\mathrm{P}^{\prime}$ may have to be changed [...] It is the purpose of this paper, then, not to stakes results but to illustrate a method of attack. (p. 156)

Additionally, 3) Piketty (2014a) argued that the popularity of Cobb and Douglas's production function is due to:

simplicity (economists like simple stories, even when they are only approximately correct) [...] but above all because the stability of the capital-labor split gives a fairly 
peaceful and harmonious view of the social order [...] in fact, it became something close to a pure ideological construct on the basis of which a justification for higher status can be elaborated. (pp. 218,331-332)

Let us learn how this author worked with Cobb and Douglas's production function, which is with $(\alpha, K)$ instead of $(k, C)$ as follows:

$$
P=b F\left[L^{\alpha} K^{(1-\alpha)}\right]
$$

Where $(P, L, K)$ represent, respectively, relative index of physical volume of production, labor, and capital combined in the production processes of an economy at each instant. "The value of b is independent" of $(L, K)$ and represents "the quantitative effects of any force" in the economy affecting production growth, and $(\alpha)$ is "the elasticity of the product with respect to small changes in labor alone" (Cobb \& Douglas, 1928, pp. 155-156). Piketty's first step was interchanging the term-exponents to get, for his convenience, the following function:

$$
P=b F\left[K^{\alpha} L^{(1-\alpha)}\right]
$$

His second step was taking the partial derivative with respect to capital at each instant, so:

$$
p_{K}=b f\left[\alpha K^{(\alpha-1)} L^{(1-\alpha)}\right]
$$

From function (18) $p_{K}=f\left[\alpha\left[b F\left[K^{\alpha} L^{(1-\alpha)}\right] / K\right]\right]$ and defining $\beta=K / P$ as the capital income ratio; $(K)$ is a stock which corresponds to the total wealth owned at a given period of time, and comes from the wealth appropriated or accumulated in all prior years combined and $(P)$ is a flow that corresponds to the quantity of goods produced and distributed in a given period (Piketty, 2014a, p. $50)$. Thus, $\left[K=\beta P \therefore K=\beta\left[b F\left(K^{\alpha} L^{(1-\alpha)}\right)\right]\right]$ which when replaced into the denominator of the previous function will yield:

$$
p_{K}=f(\alpha / \beta)
$$

And "if the return to capital is determined by the marginal productivity of capital" (Piketty, $2014 b$, p. 38), then it might be possible that $\left(p_{K}=r\right)$ and equation (19) can be converted into the next:

$$
\alpha=r \beta
$$

Which in Piketty's (2014a) words means "a pure accounting identity...though tautological, it should nevertheless be regarded as the first fundamental law of capitalism, because it expresses a simple, transparent relationship among the three most important concepts for analyzing the capitalist system [...]" (p. 52). It is clear that $\alpha$ can be derived from Cobb and Douglas's function, but $(K)$ is the quantity or the total stock of fix capital at each instant - measured as an index - used to produce goods. Meanwhile in Piketty (2014a), it "correspond[s] to the total wealth owned at a given time of period [and it] comes from the wealth appropriated or accumulated in all prior years combined" (p. 50).

Expanding Piketty's assumptions is proof that he has not gone beyond Cobb and Douglas's. By supposing marginal product of capital as $[\partial P / \partial K=\alpha P / K]$ and after replacing $\beta=K / P$ we 
obtained $[\partial P / \partial K=\alpha / \beta]$. If $\partial P / \partial K=r$ will be clear that $r=\alpha / \beta \therefore \alpha=r \beta$. Also inserting $K=\beta P$ into function (18) will yield $p_{K}=b f\left[\alpha(\beta P)^{(\alpha-1)} L^{(1-\alpha)}\right] \therefore$

$$
p_{K}=b f\left[\alpha(\beta P / L)^{(\alpha-1)}\right]
$$

If $\beta=K / P$, then $(1-\beta)=L / P$ and thus, the prior function is transformed into:

Whence, if $p_{K}=r$ :

$$
p_{K}=b f\left[\alpha(\beta /(1-\beta))^{(\alpha-1)}\right]
$$

$$
\alpha=r(\beta /(1-\beta))^{(1-\alpha)}
$$

If $(K / P / L / P)=\beta /(1-\beta) \therefore K / L=\beta /(1-\beta)$ and

$$
r=K / L
$$

is the resource composition in the economy, so $r=\beta /(1-\beta)$ which when replaced into equation (23) will give us:

$$
\alpha=\mathrm{r} r^{(1-\alpha)}
$$

This denotes that $\alpha$ is not necessarily a fixed coefficient as Cobb and Douglas (1928) had advised. Equation (22) can be expressed as the inverse of Cobb and Douglas's production function:

$$
p_{K} \cong \mathrm{r}=b f\left[\alpha r^{(\alpha-1)}\right]
$$

So, is equation (25) "a pure accounting identity" and "tautological" as Piketty (2014a, p. 52) suggested? No, it is not. Should it "be regarded as the first fundamental law of capitalism, because it expresses a simple, transparent relationship among the three most important concepts for analyzing the capitalist system..."? (Piketty, 2014a, p. 52). Yes, it could be; obtaining profits is a law in the capitalist system, and to make it possible, capital and labor must contribute productively to production growth, as is explained per function (26).

It is worth working on this even further; given $r=\beta /(1-\beta)$, the effective value of $\beta$ is $[\beta=r /(1+r)]$; it is a fact that resource composition can be measured by collecting good data on real capital stock and the number of workers in an economy. By replacing $[\beta=r /(1+r)]$ in function (21), the result is $p_{K}=b f\left[\alpha(r /(1+r) P / L)^{(\alpha-1)}\right]$.

If $L / P=(1-\beta)$, then $p_{K}=b f\left[\alpha(r /(1+r)(1 /(1-\beta)))^{(\alpha-1)}\right] \therefore p_{K}=b f[\alpha(r /(1+r) 1 /(1 /(1+r)))(\alpha-1)]$ from where function (26) emerges; it is no more than the inverse of Cobb and Douglas's relative labor contribution to production growth as we will see later in this article.

By contrasting Piketty with Swan, Solow, and Arrow et al., replacing equation (17) into (3) will result in $k=s b F\left[K^{\alpha} L^{(1-\alpha)}\right] / K$. Thus, $p_{K}=f(\alpha k / s)$ and if $p_{K}=r$, then $s r=\alpha k$ from which results Piketty's first law of capitalism equation: $\alpha=r s / k$ (Villalobos, 2019). Also, from equation (25), the rate of saving is:

$$
s=k r^{(1-\alpha)}
$$

And in terms of function (26):

$$
k=S r^{(\alpha-1)}
$$


So, what is new? And what does "beyond" mean?

\section{Resource Composition and Resource Contribution}

This section it is an endeavor to improve Cobb and Douglas's method of attack and to offer new answers to the first four questions outlined in the introduction. Taking the partial derivative of Cobb and Douglas's production function (1928) given by function (16), the additional unit of product generated by each additional unit of capital or labor alone at each instant, is found. For labor, $\partial P / \partial L=b f\left[\alpha L^{(\alpha-1)} K^{(1-\alpha)}\right] \therefore$

$$
\partial P / \partial L=b f\left[\alpha(K / L)^{(1-\alpha)}\right]
$$

and for capital, $\partial P / \partial K=b F\left[L^{\alpha}(1-\alpha) K^{(-\alpha)}\right] \therefore$

$$
\partial P / \partial K=b f\left[(1-\alpha)(K / L)^{(-\alpha)}\right]
$$

In equation (24), $(\mathrm{r})$ is the effective capital/workers composition, "a measure of the changing proportion of the two factors" (Cobb \& Douglas, 1928, p. 151). Inserting it into functions (29) and (30) will result the relative rate of contribution of labor and capital, correspondingly:

$$
\begin{gathered}
\partial P / \partial L=\lambda_{L}=b f\left(\alpha r^{(1-\alpha)}\right) \\
\partial P / \partial K=\lambda_{K}=b f\left[(1-\alpha) r^{(-\alpha)}\right]
\end{gathered}
$$

Equalizing these previous functions will yield the relative "contribution" of each additional resource to production growth according to the economy's resource composition: $\left[\alpha r^{(1-\alpha)}=(1-\alpha) r^{(-\alpha)}\right]$ so that $(1-\alpha) / \alpha=r^{(1-\alpha)} / r^{(-\alpha)}$ and thus:

$$
r=(1-\alpha) / \alpha
$$

And thus (r) is a point of convergence between resource composition and resource contribution to production growth. Labor relative contribution at each instant can be quantified by equation (33):

$$
\alpha=1 /(1+r)
$$

Thus, $\alpha$ is no longer an undefined parameter and the following hypothesis arises: The greater the resource composition ( $r$ ), the lesser the relative contribution of labor $(\alpha)$ to production growth. $\alpha$ can be measured, and Cobb and Douglas's first suggestion and questions (3) and (4) are satisfied.

After multiplying functions (31) and (32) by ( $\partial P)$, the relative and total contribution of each factor to the total product from year to year is measured. Thus, up until now and between limits, additional "contribution" of total labor and capital added is:

$$
\begin{gathered}
(\partial P / \partial L) \partial P=\rho_{L}=b f\left[\alpha r^{(1-\alpha)}\right] \partial P \\
(\partial P / \partial K) \partial P=\rho_{K}=b f\left[(1-\alpha) r^{(-\alpha)}\right] \partial P
\end{gathered}
$$


By adding these two equations together, the total relative contribution of resources at each instant is calculated:

$$
\rho=b f\left[\alpha r^{(1-\alpha)}+(1-\alpha) r^{(-\alpha)}\right] \partial P
$$

Total contribution of those resources to production growth can result by taking the partial derivative of function (16). For labor $\partial P / \partial L=b f\left[\alpha L^{(\alpha-1)} K^{(1-\alpha)}\right]=b f\left[\alpha L^{\alpha} L^{(-1)} K^{(1-\alpha)}\right]$ so that $\partial P / \partial L=[\alpha$ $\left.b F\left[L^{\alpha} K^{(1-\alpha)}\right] / L\right]$ and thus:

$$
P_{L}=(\partial P / \partial L) L=\alpha P
$$

And for capital, $\partial P / \partial K=b f\left[L^{\alpha}(1-\alpha) K^{(1-\alpha-1)}\right]=b f\left[L^{\alpha} K^{(1-\alpha)}(1-\alpha) K^{(-1)}\right]$

so that $\partial P / \partial K=\left[(1-\alpha) b F\left[L^{\alpha} K^{(1-\alpha)}\right] / K\right]$ so:

$$
(\partial P / \partial K) K=(1-\alpha) P
$$

Assuming ( $r=1)$ in equation (33), the result is $\alpha=(1-\alpha)$ and after multiplying both sides by the relative rate of growth of production $(\lambda)$, the relative rate of contribution of labor and capital to production growth is computed; for labor it is:

and for capital it is:

$$
\lambda_{L}=\alpha \lambda
$$

$$
\lambda_{K}=(1-\alpha) \lambda
$$

and the relative rate of production growth is:

$$
\lambda=\left(\lambda_{L}, \lambda_{K}\right)
$$

Total resource contribution to production growth is the addition of equations (38) and (39):

$$
P=\left(P_{L}, P_{K}\right)
$$

or: $P_{t}=P_{(t-1)}+\rho$ at each instant.

To illustrate the model proposed so far, Cobb and Douglas's data from Tables II, III and IV are useful (1928, pp. 145, 148-149). To compare the results, the values of the variables are available in Tables 1 and 2 and illustrated by Figures 1 to 4. Relative variations in production are represented by $\lambda ;[(d t / t)(\log P) \equiv \lambda]$ such that $[(d / d t) P=\lambda P / P=\lambda]$, from where the relative rate of resource contribution to production growth will result. The projections of production growth and the levels of production at each instant equal Cobb and Douglas's recorded data $(\dot{P} \approx P)$ as shown in Table 1 and Figure 2. However, this differs from those of Cobb and Douglas's estimation $\left(\dot{P} \neq P^{\prime}\right)$. By $\lambda$ from Cobb and Douglas's $P^{\prime}$, it is observed that $\left(\dot{P} \approx P^{\prime}\right) \neq P$ (Table 2, Figure 4). In both cases, the relative and total workers and capital contribution $\left(\rho_{L}, \rho_{K}\right)$ are equal as $\alpha$ tends to vary due to $(r)$ changes and $\left(\dot{P}_{L}, \dot{P}_{K}\right)$ have different value (Table 1 , Figure 1 and 3 , and Table 2 , Figure 3 ). It is important to highlight the prior fundamental results: $\alpha$ is quantifiable at each instant and with it, the relative and total resource contribution to production growth. Even so, the method of attack will be improved moving forward by making "certain further assumptions" (Cobb \& Douglas, 1928, p. 155). 
TABLE 1

RESOURCE CONTRIBUTION TO PRODUCTION GROWTH (1899-1922)

\begin{tabular}{|c|c|c|c|c|c|c|c|c|c|c|c|c|c|c|}
\hline \multirow{2}{*}{\multicolumn{4}{|c|}{$\begin{array}{c}\text { Cobb and Douglas' Recorded } \\
\text { data } \\
\text { Variables measured }\end{array}$}} & \multirow{2}{*}{\multicolumn{3}{|c|}{ Variables measured }} & \multicolumn{6}{|c|}{ Projections } & \multirow[b]{2}{*}{$\begin{array}{l}\text { Cobb- } \\
\text { Douglas' } \\
\text { calculation }\end{array}$} & \multirow[b]{2}{*}{$\begin{array}{l}\text { United States' } \\
\text { Manufactures }\end{array}$} \\
\hline & & & & & & & \multicolumn{3}{|c|}{$\begin{array}{l}\text { Relative resource } \\
\text { contribution to } \\
\text { production growth }\end{array}$} & \multirow{2}{*}{$\begin{array}{c}\begin{array}{c}\text { Level of } \\
\text { production }\end{array} \\
\dot{\mathrm{P}}\end{array}$} & \multicolumn{2}{|c|}{$\begin{array}{c}\text { Total } \\
\text { resource } \\
\text { contribution }\end{array}$} & & \\
\hline Year & $\mathrm{P}$ & $\mathrm{L}$ & $\mathrm{K}$ & $\lambda$ & $\mathrm{r}$ & $\alpha$ & $\rho_{\mathrm{L}}$ & $\rho_{\mathrm{K}}$ & $\rho$ & & $\dot{\mathrm{P}}_{\mathrm{L}}$ & $\dot{\mathrm{P}}_{\mathrm{K}}$ & $\mathrm{P}^{\prime}$ & Business cycle \\
\hline 1899 & 100 & 100 & 100 & 0,0000 & 1,0000 & 0,5000 & - & - & - & 100 & 50 & 50 & 101 & Prosperity \\
\hline 1900 & 101 & 105 & 107 & 0,0100 & 1,0190 & 0,4953 & 0,5 & 0,5 & 1,0 & 101 & 50 & 51 & 107 & $\begin{array}{l}\text { Prosperity; brief } \\
\text { recession }\end{array}$ \\
\hline 1901 & 112 & 110 & 114 & 0,1089 & 1,0364 & 0,4911 & 5,5 & 5,5 & 11,0 & 112 & 55 & 57 & 112 & Prosperity \\
\hline 1902 & 122 & 118 & 122 & 0,0893 & 1,0339 & 0,4917 & 5,0 & 5,0 & 10,0 & 122 & 60 & 62 & 121 & Prosperity \\
\hline 1903 & 124 & 123 & 131 & 0,0164 & 1,0650 & 0,4843 & 1,0 & 1,0 & 2,0 & 124 & 60 & 64 & 126 & $\begin{array}{l}\text { Prosperity; } \\
\text { recession }\end{array}$ \\
\hline 1904 & 122 & 116 & 138 & $-0,0161$ & 1,1897 & 0,4567 & $-1,0$ & $-1,0$ & $-2,0$ & 122 & 56 & 66 & 123 & $\begin{array}{l}\text { Mild depression; } \\
\text { revival }\end{array}$ \\
\hline 1905 & 143 & 125 & 149 & 0,1721 & 1,1920 & 0,4562 & 10,5 & 10,5 & 21,1 & 143 & 65 & 78 & 133 & Prosperity \\
\hline 1906 & 152 & 133 & 163 & 0,0629 & 1,2256 & 0,4493 & 4,5 & 4,5 & 9,1 & 152 & 68 & 84 & 141 & Prosperity \\
\hline 1907 & 151 & 138 & 176 & $-0,0066$ & 1,2754 & 0,4395 & $-0,5$ & $-0,5$ & $-1,0$ & 151 & 66 & 85 & 148 & $\begin{array}{l}\text { Prosperity; } \\
\text { panic; } \\
\text { recession; } \\
\text { depression }\end{array}$ \\
\hline 1908 & 156 & 121 & 185 & 0,0331 & 1,5289 & 0,3954 & 2,6 & 2,6 & 5,1 & 156 & 62 & 94 & 137 & Depression \\
\hline 1909 & 125 & 140 & 198 & $-0,1987$ & 1,4143 & 0,4142 & $-15,8$ & $-15,8$ & $-31,5$ & 125 & 52 & 73 & 155 & $\begin{array}{l}\text { Revival; Mild } \\
\text { prosperity }\end{array}$ \\
\hline 1910 & 159 & 144 & 208 & 0,2720 & 1,4444 & 0,4091 & 17,2 & 17,2 & 34,5 & 159 & 65 & 94 & 160 & Recession \\
\hline 1911 & 153 & 145 & 216 & $-0,0377$ & 1,4897 & 0,4017 & $-3,1$ & $-3,1$ & $-6,1$ & 153 & 61 & 92 & 163 & Mild depression \\
\hline 1912 & 177 & 152 & 226 & 0,1569 & 1,4868 & 0,4021 & 12,2 & 12,2 & 24,5 & 178 & 71 & 106 & 170 & $\begin{array}{l}\text { Revival; } \\
\text { prosperity }\end{array}$ \\
\hline 1913 & 184 & 154 & 236 & 0,0395 & 1,5325 & 0,3949 & 3,6 & 3,6 & 7,2 & 185 & 73 & 112 & 174 & $\begin{array}{l}\text { Prosperity; } \\
\text { recession }\end{array}$ \\
\hline 1914 & 169 & 149 & 244 & $-0,0815$ & 1,6376 & 0,3791 & $-7,8$ & $-7,8$ & $-15,5$ & 169 & 64 & 105 & 171 & Depression \\
\hline 1915 & 189 & 154 & 266 & 0,1183 & 1,7273 & 0,3667 & 10,4 & 10,4 & 20,8 & 190 & 70 & 120 & 179 & $\begin{array}{l}\text { Revival; } \\
\text { prosperity }\end{array}$ \\
\hline 1916 & 225 & 182 & 298 & 0,1905 & 1,6374 & 0,3792 & 18,6 & 18,6 & 37,3 & 227 & 86 & 141 & 209 & Prosperity \\
\hline 1917 & 227 & 196 & 335 & 0,0089 & 1,7092 & 0,3691 & 1,0 & 1,0 & 2,1 & 229 & 85 & 145 & 227 & $\begin{array}{l}\text { Prosperity; war } \\
\text { activity }\end{array}$ \\
\hline 1918 & 223 & 200 & 366 & $-0,0176$ & 1,8300 & 0,3534 & $-2,1$ & $-2,1$ & $-4,2$ & 225 & 80 & 146 & 236 & $\begin{array}{l}\text { War activity; } \\
\text { recession }\end{array}$ \\
\hline 1919 & 218 & 193 & 387 & $-0,0224$ & 2,0052 & 0,3328 & $-2,7$ & $-2,7$ & $-5,3$ & 220 & 73 & 147 & 233 & $\begin{array}{l}\text { Revival; } \\
\text { prosperity }\end{array}$ \\
\hline 1920 & 231 & 193 & 407 & 0,0596 & 2,1088 & 0,3217 & 7,0 & 7,0 & 14,0 & 234 & 75 & 159 & 236 & $\begin{array}{l}\text { Prosperity; } \\
\text { recession; } \\
\text { depression }\end{array}$ \\
\hline 1921 & 179 & 147 & 417 & $-0,2251$ & 2,8367 & 0,2606 & $-29,7$ & $-29,7$ & $-59,3$ & 174 & 45 & 129 & 194 & Depression \\
\hline 1922 & 240 & 161 & 431 & 0,3408 & 2,6770 & 0,2720 & 33,1 & 33,1 & 66,2 & 241 & 65 & 175 & 209 & $\begin{array}{l}\text { Revival; } \\
\text { prosperity }\end{array}$ \\
\hline
\end{tabular}

Source: Elaborated by the author (based on Cobb and Douglas's data) 


\section{FIGURE 1 \\ TREND OF RESOURCE COMPOSITION}

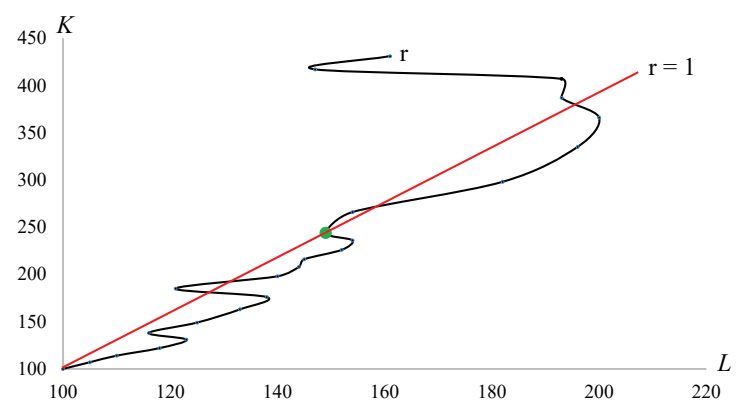

Source: Elaborated by the author (based on Table 1)

FIGURE 2

RECORDED AND PROJECTIONS OF PRODUCTION GROWTH (1899-1922)

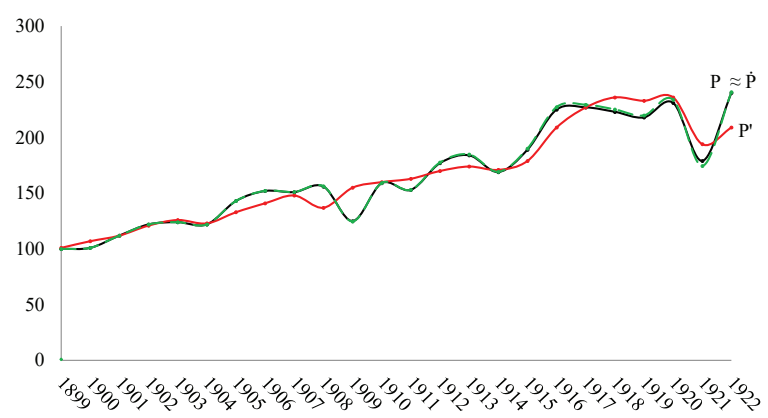

Source: Elaborated by the author (based on Table 1)

FIGURE 3

TREND OF TOTAL RESOURCE CONTRIBUTION TO PRODUCTION GROWTH (1899-1922)

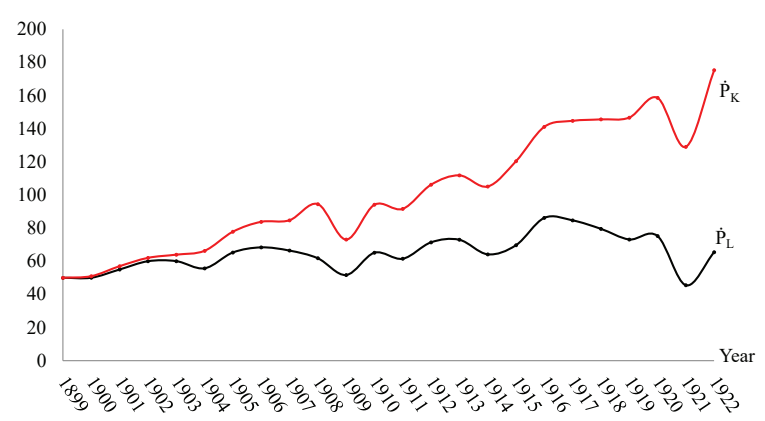

Source: Elaborated by the author (based on Table 1) 
TABLE 2

RESOURCE CONTRIBUTION TO PRODUCTION GROWTH (1899-1922)

\begin{tabular}{|c|c|c|c|c|c|c|c|c|c|c|c|c|c|c|}
\hline \multirow{2}{*}{\multicolumn{4}{|c|}{$\begin{array}{l}\text { Cobb and Douglas' Recorded } \\
\text { data }\end{array}$}} & \multirow{2}{*}{\multicolumn{3}{|c|}{ Variables measured }} & \multicolumn{6}{|c|}{ Projections } & \multirow[b]{2}{*}{$\begin{array}{c}\text { Cobb- } \\
\text { Douglas' } \\
\text { calculation }\end{array}$} & \multirow[b]{2}{*}{$\begin{array}{l}\text { United States } \\
\text { Manufactures }\end{array}$} \\
\hline & & & & & & & \multicolumn{3}{|c|}{$\begin{array}{l}\text { Relative resource } \\
\text { contribution to } \\
\text { production growth }\end{array}$} & \multirow{2}{*}{$\begin{array}{c}\begin{array}{c}\text { Level of } \\
\text { production }\end{array} \\
\dot{\mathrm{P}}\end{array}$} & \multicolumn{2}{|c|}{$\begin{array}{c}\text { Total } \\
\text { resource } \\
\text { contribution }\end{array}$} & & \\
\hline Year & $\mathrm{P}$ & $\mathrm{L}$ & K & $\lambda$ & $\mathrm{r}$ & $\alpha$ & $\rho_{\mathrm{L}}$ & $\rho_{\mathrm{K}}$ & p & & $\dot{\mathrm{P}}_{\mathrm{L}}$ & $\dot{\mathrm{P}}_{\mathrm{K}}$ & $\mathrm{P}^{\prime}$ & $\begin{array}{l}\text { Business } \\
\text { cycle }\end{array}$ \\
\hline 1899 & 100 & 100 & 100 & 0,0000 & 1,0000 & 0,5000 & - & - & - & 100 & 50 & 50 & 101 & Prosperity \\
\hline 1900 & 101 & 105 & 107 & 0,0594 & 1,0190 & 0,4953 & 3,0 & 3,0 & 5,9 & 106 & 52 & 53 & 107 & $\begin{array}{l}\text { Prosperity; } \\
\text { brief recession }\end{array}$ \\
\hline 1901 & 112 & 110 & 114 & 0,0467 & 1,0364 & 0,4911 & 2,5 & 2,5 & 5,0 & 111 & 54 & 56 & 112 & Prosperity \\
\hline 1902 & 122 & 118 & 122 & 0,0804 & 1,0339 & 0,4917 & 4,5 & 4,5 & 8,9 & 120 & 59 & 61 & 121 & Prosperity \\
\hline 1903 & 124 & 123 & 131 & 0,0413 & 1,0650 & 0,4843 & 2,5 & 2,5 & 5,0 & 125 & 60 & 64 & 126 & $\begin{array}{l}\text { Prosperity; } \\
\text { recession }\end{array}$ \\
\hline 1904 & 122 & 116 & 138 & $-0,0238$ & 1,1897 & 0,4567 & $-1,5$ & $-1,5$ & $-3,0$ & 122 & 56 & 66 & 123 & $\begin{array}{l}\text { Mild } \\
\text { depression; } \\
\text { revival }\end{array}$ \\
\hline 1905 & 143 & 125 & 149 & 0,0813 & 1,1920 & 0,4562 & 5,0 & 5,0 & 9,9 & 132 & 60 & 72 & 133 & Prosperity \\
\hline 1906 & 152 & 133 & 163 & 0,0602 & 1,2256 & 0,4493 & 4,0 & 4,0 & 8,0 & 140 & 63 & 77 & 141 & Prosperity \\
\hline 1907 & 151 & 138 & 176 & 0,0496 & 1,2754 & 0,4395 & 3,5 & 3,5 & 7,0 & 147 & 64 & 82 & 148 & $\begin{array}{l}\text { Prosperity; } \\
\text { panic; } \\
\text { recession; } \\
\text { depression }\end{array}$ \\
\hline 1908 & 156 & 121 & 185 & $-0,0743$ & 1,5289 & 0,3954 & $-5,6$ & $-5,6$ & $-11,1$ & 136 & 54 & 82 & 137 & Depression \\
\hline 1909 & 125 & 140 & 198 & 0,1314 & 1,4143 & 0,4142 & 9,0 & 9,0 & 18,1 & 154 & 64 & 90 & 155 & $\begin{array}{l}\text { Revival; Mild } \\
\text { prosperity }\end{array}$ \\
\hline 1910 & 159 & 144 & 208 & 0,0323 & 1,4444 & 0,4091 & 2,5 & 2,5 & 5,0 & 159 & 65 & 94 & 160 & Recession \\
\hline 1911 & 153 & 145 & 216 & 0,0188 & 1,4897 & 0,4017 & 1,5 & 1,5 & 3,0 & 162 & 65 & 97 & 163 & $\begin{array}{l}\text { Mild } \\
\text { depression }\end{array}$ \\
\hline 1912 & 177 & 152 & 226 & 0,0429 & 1,4868 & 0,4021 & 3,5 & 3,5 & 7,1 & 169 & 68 & 101 & 170 & $\begin{array}{l}\text { Revival; } \\
\text { prosperity }\end{array}$ \\
\hline 1913 & 184 & 154 & 236 & 0,0235 & 1,5325 & 0,3949 & 2,0 & 2,0 & 4,1 & 173 & 68 & 105 & 174 & $\begin{array}{l}\text { Prosperity; } \\
\text { recession }\end{array}$ \\
\hline 1914 & 169 & 149 & 244 & $-0,0172$ & 1,6376 & 0,3791 & $-1,5$ & $-1,5$ & $-3,1$ & 170 & 64 & 105 & 171 & Depression \\
\hline 1915 & 189 & 154 & 266 & 0,0468 & 1,7273 & 0,3667 & 4,1 & 4,1 & 8,2 & 178 & 65 & 113 & 179 & $\begin{array}{l}\text { Revival; } \\
\text { prosperity }\end{array}$ \\
\hline 1916 & 225 & 182 & 298 & 0,1676 & 1,6374 & 0,3792 & 15,4 & 15,4 & 30,7 & 209 & 79 & 130 & 209 & Prosperity \\
\hline 1917 & 227 & 196 & 335 & 0,0861 & 1,7092 & 0,3691 & 9,3 & 9,3 & 18,6 & 227 & 84 & 143 & 227 & $\begin{array}{l}\text { Prosperity; } \\
\text { war activity }\end{array}$ \\
\hline 1918 & 223 & 200 & 366 & 0,0396 & 1,8300 & 0,3534 & 4,7 & 4,7 & 9,4 & 237 & 84 & 153 & 236 & $\begin{array}{l}\text { War activity; } \\
\text { recession }\end{array}$ \\
\hline 1919 & 218 & 193 & 387 & $-0,0127$ & 2,0052 & 0,3328 & $-1,6$ & $-1,6$ & $-3,2$ & 234 & 78 & 156 & 233 & $\begin{array}{l}\text { Revival; } \\
\text { prosperity }\end{array}$ \\
\hline 1920 & 231 & 193 & 407 & 0,0129 & 2,1088 & 0,3217 & 1,6 & 1,6 & 3,2 & 237 & 76 & 161 & 236 & $\begin{array}{l}\text { Prosperity; } \\
\text { recession; } \\
\text { depression }\end{array}$ \\
\hline 1921 & 179 & 147 & 417 & $-0,1780$ & 2,8367 & 0,2606 & $-23,7$ & $-23,7$ & $-47,5$ & 189 & 49 & 140 & 194 & Depression \\
\hline 1922 & 240 & 161 & 431 & 0,0773 & 2,6770 & 0,2720 & 8,2 & 8,2 & 16,3 & 206 & 56 & 150 & 209 & $\begin{array}{l}\text { Revival; } \\
\text { prosperity }\end{array}$ \\
\hline
\end{tabular}

Source: Elaborated by the author (based on Cobb and Douglas's data) 
FIGURE 4

\section{RECORDED AND PROJECTIONS OF PRODUCTION GROWTH (1899-1922)}

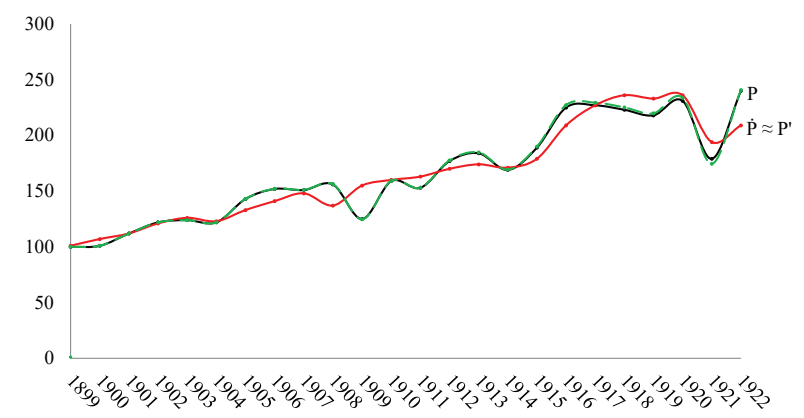

Source: Elaborated by the author (based on Table 2)

\section{Resource Composition and Distribution of Value}

Proportional changes in resource composition can be provided by equation (24): $(d t / t)(\log (r))=d t / t[\log (K / L)] \equiv$

$$
\dot{r}=k-n
$$

This equation explains that relative changes in the amount of resources might affect the level of resource composition ( $r$ ), as it was perceived in the previous section of this research. The previous equation is the nucleus of Solow's fundamental equation analyzed in the first section. Let $(k, n, \dot{r})$ be, correspondingly, the relative rates of growth of capital, labor, and resource composition. If $(k=0)$, from equation (44) $(\dot{r}=-n)$ and resource composition will vary at the inverse direction of $(n)$. If $(n=0)$, then $(\dot{r}=k)$ and resource composition will change in the same direction as $k$. If $(n=k)$, then $(\dot{r}=0)$ meaning that resource composition remains the same value, but it does not necessarily imply constant returns to scale. Taken the partial derivative of equation (24) with respect to capital and to labor, the relative influence of each factor on resource composition is measured.

Thus $\partial r / \partial K=1 / L \therefore \partial r_{K}=(1 / L) \partial K=k r$, which explains relative changes in resource composition by small variations in the quantity of capital alone.

Furthermore, $\partial r / \partial L=(-1 / L)(K / L) \therefore \partial r_{L}=-\partial L / L \quad r=-n r$ revels relative changes in resource composition because of small changes in the amount of labor alone. By equalizing those results such that $k r=-n r \therefore-n / k=1$, and defining $\mu=/-n / k / ;\{\mu \geq 0\}$ will yield the elasticity-of-resource composition. So, small changes on resources and production do matter in economic analysis!

Making "certain further assumptions" (Cobb \& Douglas, 1928, p. 155) will bring about a new "method of attack" (Cobb \& Douglas, 1928, p. 165), which discloses the distribution phenomenon. Let us transform Cobb and Douglas's production function into a function of distribution of production as follows:

$$
P=b F\left(L^{\beta} K^{(1-\beta)}\right)
$$

$\beta$ becomes the elasticity-of-distribution of production growth between capital and labor. Replacing $\left(K=r L\right.$ ) from equation (24) in function (45) will result in $P=b F\left(r^{(1-\beta)}\right) L$ and after differentiating and simplifying:

$$
\lambda P=b f\left(r^{(1-\beta)}\right) n L
$$


Furthermore, from equation (24), it is also true that $(\mathrm{L}=1 / \mathrm{r} \mathrm{K})$, which once replaced into equation (16) will give $P=b F\left[(1 / r K)^{\beta} K^{(1-\beta)}\right] \therefore P=b F\left[(1 / r)^{\beta} K\right]$ and after taking its derivative:

$$
\lambda P=b f\left[(1 / r)^{\beta}\right] k K
$$

Equalizing functions (46) and (47) it is revealed that $\mu=1$ if $k=n$ which is the case when (r) remains the same and no warranty of constant return to scale, due to resources' productivity.

Function (46) can be transmuted into:

$$
\left(\lambda_{L}=b f\left(r^{(1-\beta)}\right) n \beta\right.
$$

It represents the relative labor share on production growth or its relative income. Function (47) can be renewed into:

$$
\lambda_{K}=b f\left[(1 / r)^{\beta}\right](1-\beta) k
$$

This amounts to capital share on production growth or its relative income. Harmonizing these two functions results in:

$$
\beta=\frac{1}{1+\mu r} ;\left[\lim _{\mu \rightarrow 0} F(\mu)=\lim _{\mu \rightarrow 0} \frac{1}{1+\mu r} \cong 1 ; \lim _{\mu \rightarrow \infty} F(\mu)=\lim _{\mu \rightarrow \infty} \frac{1}{1+\mu r} \cong 0\right] \therefore \beta:(0,1)
$$

This measures the slope of the curve of incremental product going to labor and to capital: $\beta$ could differ from $(\alpha)$ in equation (34), having now a composite meaning; the elasticity-ofdistribution of production growth $(\beta)$ might change with respect to the elasticity-of-resource composition $\mu$ and $(r)$. While $\alpha$ measures labor relative contribution to production growth due to relative changes in $(r), \beta$ appraises the relative amount of product going to labor due to relative oscillations in $(\mu, r)$. This suggests that $\mu$ oscillations around (r) might generate income divergences.

The total share of resources on production growth can be obtained by taking the partial derivative of function (45) once again: For labor $\partial P / \partial L=b f\left[\beta L^{(\beta-1)} K^{(1-\beta)}\right]$ so that $\partial P / \partial L=\left[\beta b F\left[L^{\beta}\right.\right.$ $\left.\left.K^{(1-\beta)}\right] / L\right]$ and thus:

$$
P_{L}=(\partial P / \partial L) L=\beta P
$$

In the case of capital, $\partial P / \partial K=b f\left[L^{\beta}(1-\beta) K^{(1-\beta-1)}\right]=b f\left[L^{\beta} K^{(1-\beta)}(1-\beta) K^{(-1)}\right]$ so that $\partial P / \partial K=\left[(1-\beta) b F\left[L^{\beta} K^{(1-\beta)}\right] / K\right]$ and so:

$$
P_{K}=(\partial P / \partial K) K=(1-\beta) P
$$

Assuming $(\mu=1) ;(k=n),(\dot{r}=0)$ the effective rate of production growth going to labor is:

$$
\lambda_{L}=\beta \lambda
$$

and for capital it is:

$$
\lambda_{K}=(1-\beta) \lambda
$$

and the relative rate of production growth in the economy is:

$$
X=\left(X_{L}, X_{K}\right)
$$


When production falls, the larger the elasticity of resource composition is, and the smaller the relative contribution of labor is as compared to capital. The effective relative income of labor can be calculated multiplying equation $(53)$ by $(P)$ :

$$
W=\beta \lambda P
$$

And total workers' income is:

$$
W=\beta P
$$

Capital income will surge by multiplying equation (54) by $(P)$ :

$$
\omega=(1-\beta) \lambda P
$$

And total capital income is:

$$
\omega=(1-\beta) P
$$

Relative labor and capital contributions $\left(\lambda_{L}, \lambda_{K}\right)$ are related to relative labor and capital incomes $\left(\lambda_{L}, X_{K}\right)^{2}$. Convergence is a result of $(r)$ defining $(\alpha)$ while divergence will appear due to $(n, k ; \mu)$ determining $(\beta)$ at each instant. In summary, $(n, k)$ indicate changes in the amount of resources in the production process and at the same time, the fluctuations of (r). Technological changes or resource use intensity at different market conditions might affect production growth and its distribution between capital and labor (Villalobos, 2019).

From Cobb and Douglas's (1928) data, the calculation for each variable of the model is shown in Table 3; $(\dot{P}=P)$ and, as stated in the core purpose of this research, "the processes of distribution are modeled at all closely upon those of the production of value" as (Cobb \& Douglas, 1928, pp. 139$140,161)$ suggested but did not reveal. All the results of resource contribution to production growth are adjusted by the formulas (37) to (43) and distribution of value by formulas (44) to (59). Relative resource contribution to resource composition strongly oscillates along those years, making resource composition increasingly steady. Labor relative rate of productivity was slightly decreased while its relative share declined fairly unstably and unfavorably compared to capital.

The relative rates of labor contribution to production growth declined over the period more than capital did, and it was smaller than that of capital. This result is congruent with the relation between the relative rate of production growth and those of capital and labor; labor showed a larger dispersion while capital remained relatively concentrated. However, labor's share on production growth was a bit smaller than labor's contribution to production growth, all the contrary for capital whose productivity exceeded that of labor. But the propensity of labor contribution to production growth was to decrease as resource composition rose while the tendency of labor's share on production growth was to increase as the elasticity of resource composition grew.

Capital and labor contribution to production growth converges with capital and labor income at changes in resource composition. It seems that "the processes of distribution are modeled at all closely upon those of the production of value" (Cobb \& Douglas, 1928, pp. 139-140, 161). It is

2 Functions (46) and (47) provide the equivalence and divergence between marginal share and marginal contribution of resources as per equations (51 to 59); let us see: $\lambda P / n L=b f\left(r^{(1-\beta)}\right) \therefore \rho=b f\left(r^{(1-\beta)}\right) \lambda P$ and $\rho_{L}=b f\left(r^{(1-\beta)}\right) \beta \lambda P ; \lambda P / k K=b f\left[(1 / r)^{\beta}\right] \therefore$ $\omega \dot{\omega}=b f\left[(1 / r)^{\beta}\right] \lambda P$ and $\rho_{K}=b f\left[(1 / r)^{\beta}\right](1-\beta) \lambda P$. 
not clear if an "increase in production was purely fortuitous" or "whether it was primarily caused by technique, and the degree, if any, to which it responded to changes in the quantity of labor or capital" (Cobb \& Douglas, 1928, pp. 139-140). If fortuitous means opportunity, production and distribution of value were related to all those factors and to business cycle and wars. Erratic oscillation of the elasticity of resource composition can be especially related to labor instability; it is possible to affirm that to some degree, production increases since 1910 was caused by technique, as it could be deduced by the high level of $(\mu)$ due to substitution of labor for capital. After all, convergence in the production process could entail divergence with equity or inequality in the distribution process.

According to the results, when $(0<\mu \leq 1)$, the divergence between the relative rates of return and wage is smaller than that out of the range. This particularly involves times of prosperity, and it appears to happen even at $(0.9 \leq \mu<2)$. Production and distribution of value implied the convergence and divergence phenomenon along those years, and it seems that the higher $(\mu)$, the higher labor relative income, but the lower its productivity as compared to capital, for which the larger $(\mu)$, the smaller its relative increase of income.

We attempted to hypothesize that in those years, the tendency of profit $(r)$ was to fall in the long run as $(\mu)$ turned increasingly ${ }^{3}$ while the tendency of the relative labor income $(\dot{w})$ grew. The same tendency showed the relative and total capital and labor incomes. Relative and total capital income steadily increased in those years while relative and total labor income remained relatively constant.

3 Marx (1986) described such phenomenon as the law of the tendency of the rate of profit to fall, attributing it to a gradual increase in the accumulation of capital. The relative fall in the rate of profit may not prevent gross profit to grow steadily (Villalobos, 2010). 
TABLE 3

PRODUCTION GROWTH: CAPITAL AND LABOR CONTRIBUTION AND DISTRIBUTION (1899-1922)

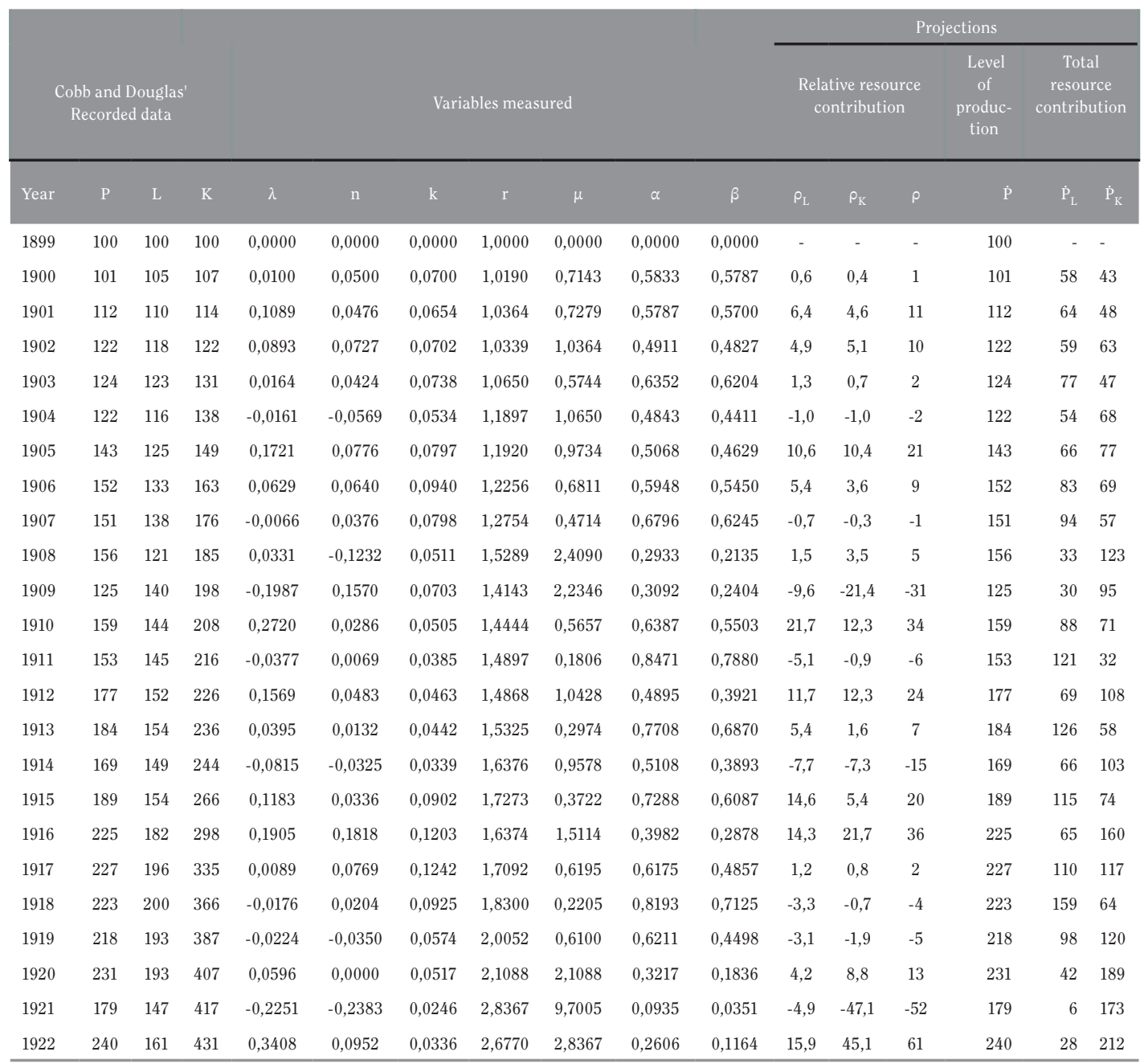

Source: Elaborated by the author (based on Cobb and Douglas's data) 
TABLE 3

PRODUCTION GROWTH: CAPITAL AND LABOR CONTRIBUTION AND DISTRIBUTION $(1899-1922)$ (Continuation)

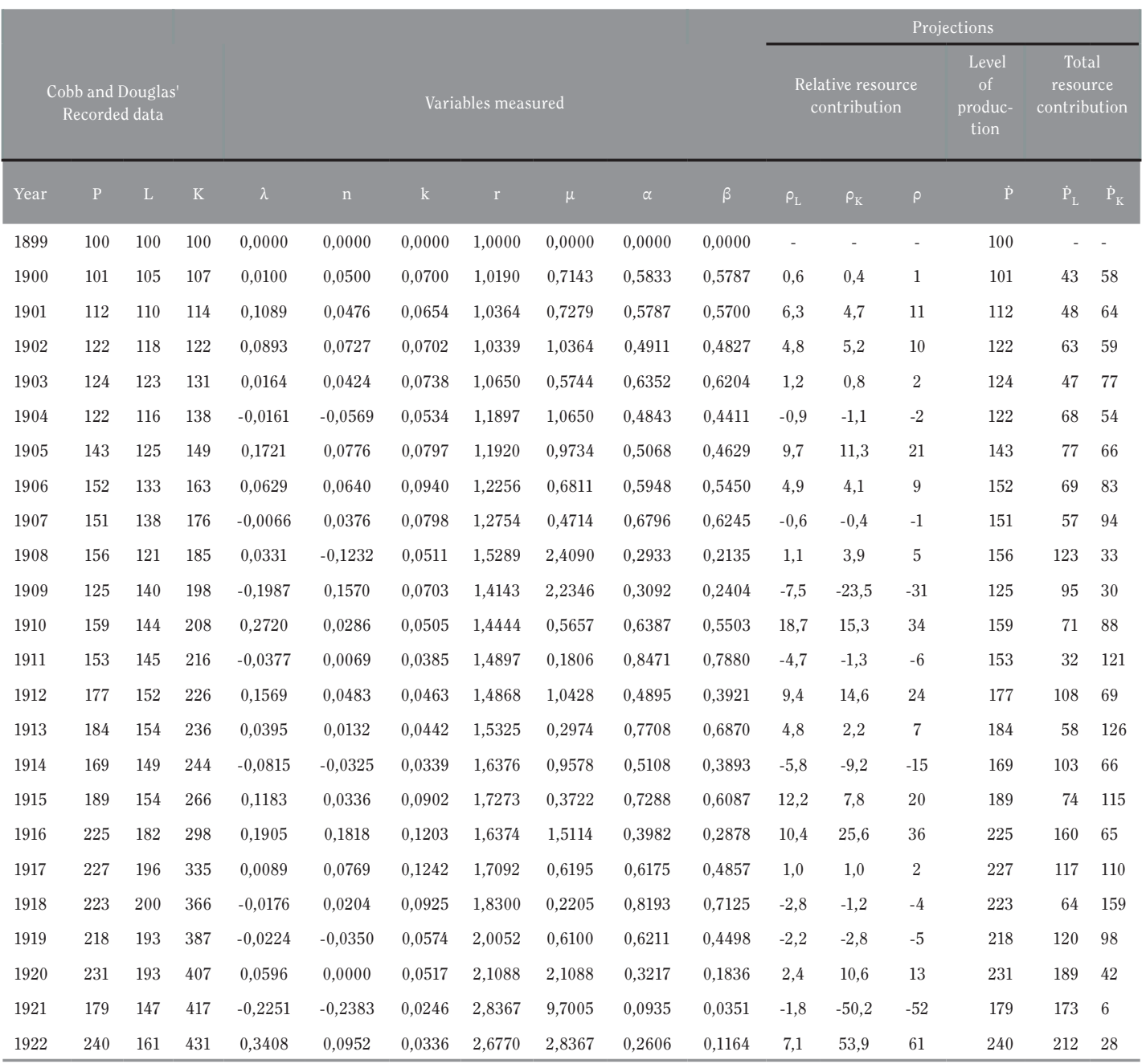

Source: Elaborated by the author (based on Cobb and Douglas's data) 


\section{CONCLUSIONS}

As stated in the introduction, the purpose of this study was to offer answers to those five Cobb and Douglas questions that the refinement in economic growth theory has not yet provided. To deal with this, we started framing a new method of attack. This led us to pay special attention to Cobb and Douglas's suggestion and challenge related to the necessity of providing new formulas and working with tendencies of capital, labor, and production in dealing with economic growth. It was not possible to prove if production growth is purely fortuitous or just fortuitous, but perhaps it is clear that it can be commanded by changes in the processes of production and distribution of values. This could imply variations not only in the amount of capital and labor but also in market conditions, government policies, and specifically innovations in the processes of production of goods as capital (machinery, buildings, transportation, infrastructure, raw materials, and the advances on apply science) as well as in labor education and abilities. All these factors change the way resources influence the path of production growth in the long term and compare its relative and total contribution and its share on production growth.

As resource composition changes along a period of time, it is feasible to measure the quantity of product added by each unit of capital and labor and by the additional resource used in the production process at each instant. The influence of changes in techniques and abilities and in any other factor can be indirectly measured by the resource productivity. The purpose of the new formulas in this research is to measure the elasticity of resource composition, the elasticity of resource contribution to production growth, and the elasticity of distribution of production growth at each instant. These elasticities give greater definiteness that the slopes of the curves of cost and of the relative and total contribution and distribution have quantitative values. By working with Cobb and Douglas's data, all those questions seem to have, at least tentatively, answers according to the results of the analysis in this study. Based on this research, the fundamental conclusion is that "the processes of distribution are modeled at all closely upon those of the production of value," a core Cobb and Douglas's (1928) concern. Harrod (1939) was right when he said that "once the mind is accustomed to thinking in terms of trends of increase, the old static formulation of problems seems stale, flat and unprofitable" (p. 15).

By making further assumptions, the same analysis can be made to explain the cost of production, determining resources' relative contribution to cost and then contrasting it with resource income. Some additional assumptions must include other variables with influences in economic growth, such as prices of capital goods and its attributes, working capital and fixed capital, and market rivalry. One special limitation to this research is having used Cobb and Douglas's data (1899-1922) to evaluate the proposed refinement of the method of attack. However, there are opportunities of doing it for any particular economy, industry, or firm, as well as improving the method of attack and model of analysis. 


\section{REFERENCES}

Arrow, J. K., Chenery, B. H., Minhas, S. B., \& Solow, M. R. (1961). Capital-Labor substitution and economic efficiency. The Review of Economics and Statistics, XLIII(3), 225-250. https://doi.org/10.2307/1927286

Cobb, W. C., \& Douglas, H. P. (1928). A theory of production. The American Economic Review, 18(1), 139-165. JSTOR.

Harrod, R. F. (1939). An essay in dynamic theory. The Economic Journal, 49(193), 14-33. https://doi.org/10.2307/2225181

Harrod, R. F. (1960). Second essay in dynamic theory. The Economic Journal, 70(178), 277-293. https://doi.org/10.2307/2228728

Marx, K. (1986). El capital (8a ed., Vols. VI, Tomo III). Siglo XXI.

Piketty, T. (2014a). Capital in the twenty-first century. London: The Belknap Press of Harvard University Press.

Piketty, T. (2014b, March 06). Technical appendix of the book "Capital in the twenty-first century». (H. U. Press, Ed.). http://piketty.pse.ens.fr/capital21c

Solow, M. R. (1956). A contribution to the theory of economic growth. The Quarterly Journal of Economics, 70(1), 65-94. https://doi.org/10.2307/1884513

Solow, M. R. (1957). Technical change and the aggregate production function. The Review of Economics and Statistics, 39(3), 312-320. https://doi.org/10.2307/1926047

Swan, T. W. (1956, Noviembre). Economic growth and capital accumulation. Economic Record(32), 334-361. https://doi.org/10.1111/j.1475-4932.1956.tb00434.x

Villalobos, D. (2019). Crecimiento económico: Convergencia y divergencia. Economía y Sociedad, 24(55), 1-30. https://doi.org/10.15359/eys.24-55.3

Villalobos, D. (2010). Capital, Competencia y Ganancia (Primera ed.). Editorial Universidad Nacional de Costa Rica.

Villalobos, D. (2020). Economic growth: Productivity, thrift and capital accumulation. Economía y Sociedad, 25(57), 1-30. https://doi.org/10.15359/eys.25-57.4

Este artículo se encuentra disponible mediante la licencia Creative Commons Reconocimiento-NoComercial-SinObraDerivada 3.0 Costa Rica. Para mayor información escribir a revista.iice@ucr.ac.cr. 